$\mathrm{DE}$

M E D I C I N A

T R O P I C A L

$\mathrm{DE}$

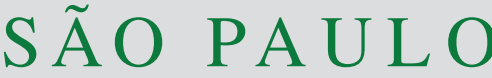

JOURNAL OF THE SÃO PAULO INSTITUTE OF TROPICAL MEDICINE

${ }^{1}$ Universidade Estadual Paulista, Faculdade de Medicina Veterinária e Zootecnia, Departamento de Higiene Veterinária e Saúde Pública, Botucatu, São Paulo, Brazil

¿Universidade de São Paulo, Faculdade de Medicina Veterinária e Zootecnia, Departamento de Medicina Veterinária Preventiva e Saúde Animal, São Paulo, São Paulo, Brazil

${ }^{3}$ Universidade de Nariño, Departamento de Biología, Nariño, Colombia

${ }^{4}$ Universidade do Rio Verde, Rio Verde, Goiás, Brazil

Correspondence to: Márcio Garcia Ribeiro Universidade Estadual Paulista, Faculdade de Medicina Veterinária e Zootecnia, Departamento de Higiene Veterinária e Saúde Pública, PO Box 560, CEP 18618681, Botucatu, SP, Brazil

Tel: +55 1438802102 .

E-mail: mgribeiro@fmvz.unesp.br

Received: 03 August 2017

Accepted: 30 November 2017

\section{Nontuberculous mycobacteria in milk from positive cows in the intradermal comparative cervical tuberculin test: implications for human tuberculosis infections}

\author{
Carmen Alicia Daza Bolaños ${ }^{1}$, Marília Masello Junqueira Franco', Antonio \\ Francisco Souza Filho², Cássia Yumi Ikuta², Edith Mariela Burbano-Rosero ${ }^{3}$, \\ José Soares Ferreira Neto², Marcos Bryan Heinemann², Rodrigo Garcia \\ Motta $^{4}$, Carolina Lechinski de Paula', Amanda Bonalume Cordeiro de \\ Morais ${ }^{1}$, Simony Trevizan Guerra', Ana Carolina Alves' ${ }^{1}$, Fernando José \\ Paganini Listoni ${ }^{1}$, Márcio Garcia Ribeiro ${ }^{1}$
}

\section{ABSTRACT}

Although the tuberculin test represents the main in vivo diagnostic method used in the control and eradication of bovine tuberculosis, few studies have focused on the identification of mycobacteria in the milk from cows positive to the tuberculin test. The aim of this study was to identify Mycobacterium species in milk samples from cows positive to the comparative intradermal test. Milk samples from 142 cows positive to the comparative intradermal test carried out in 4,766 animals were aseptically collected, cultivated on Lowenstein-Jensen and Stonebrink media and incubated for up to 90 days. Colonies compatible with mycobacteria were stained by Ziehl-Neelsen to detect acid-fast bacilli, while to confirm the Mycobacterium genus, conventional PCR was performed. Fourteen mycobacterial strains were isolated from 12 cows $(8.4 \%)$. The $h s p 65$ gene sequencing identified $M$. engbaekii $(\mathrm{n}=5), M$. arupense $(\mathrm{n}=4), M$. nonchromogenicum $(\mathrm{n}=3)$, and $M$. heraklionense $(\mathrm{n}=2)$ species belong to the Mycobacterium terrae complex. Despite the absence of $M$. tuberculosis complex species in the milk samples, identification of these mycobacteria highlights the risk of pathogen transmission from bovines to humans throughout milk or dairy products, since many of mycobacterial species described here have been reported in pulmonary and extrapulmonary diseases both in immunocompetent and immunocompromised people.

KEYWORDS: $M$. terrae complex. Bovine. Intradermal tuberculin tests. Sequencing.

\section{INTRODUCTION}

The genus Mycobacterium comprises a wide range of organisms, including (i) obligate pathogens belonging to the M. tuberculosis complex, which cause serious human and animal diseases; (ii) opportunistic or potential pathogens, mainly represented by the $M$. avium-intracellulare complex; and (iii) saprophytic species ${ }^{1}$. Historically, M. tuberculosis and M. bovis are the major pathogenic species of human and bovine infections caused by this pathogen, respectively. NTM species are emerging causes of human diseases of global significance ${ }^{2}$, and this group of mycobacteria has been increasingly reported as primary pathogens causing pulmonary and extrapulmonary infections ${ }^{3}$.

Tuberculosis remains one of the major cattle infectious diseases worldwide, due to losses caused by reduced meat and milk yield, carcass condemnation in 
slaughterhouses, and embargoes to the trade of cattle products, as well as the zoonotic potential of the pathogen, particularly due to its presence in milk ${ }^{4}$.

Milk is well-recognized as a potential vehicle for bovine-to-human pathogen transmission, particularly for $M$. bovis or $\mathrm{NTM}^{5}$. Although pasteurization kills mycobacteria, raw milk consumption is a habit that remains in some countries, and this pathogen represents public health threats; as it was estimated that M. bovis is the primary agent of $2 \%$ pulmonary and $8 \%$ extrapulmonary infections in humans ${ }^{6}$. Although the single and intradermal comparative cervical tests represent the main in vivo diagnostic method used in the control and eradication of the disease in bovine, globally ${ }^{7}$, few studies have focused on the identification of mycobacteria in milk from positive cows in tuberculin tests $^{8}$. In addition, mycobacteria other than $M$. bovis, such as NTM, may interfere with current intradermal diagnostic tests for bovine tuberculosis ${ }^{9}$.

Routine laboratory diagnosis of mycobacteria is based on microbiological culture and biochemical tests. Nevertheless, these conventional procedures may take several weeks, are laborious, and sometimes fail to provide a precise species identification. In this scenario, various molecular methods have been developed for rapid detection of mycobacteria ${ }^{10,11}$. Among these methods, targeting $h s p 65$ gene and DNA sequencing are valuable techniques for microbiological confirmation and typing of mycobacteria species of animal origin ${ }^{12}$. The aim of this study was to identify species of mycobacteria by microbiological and molecular methods in the milk from cows positive to the intradermal comparative cervical tuberculin test.

\section{MATERIAL AND METHODS}

This study was approved by the Ethics Committee on Animal Use (CEUA) guidelines at FMVZ-UNESP/ Botucatu, SP (protocol Nº 96/2014).

\section{Animals and tuberculin test}

Between August 2014 and August 2015, from 15 counties in the State of Paraná, Brazil, 4,766 lactating animals were tested with the intradermal comparative cervical tuberculin test; out of them, 142 animals were positive. The intradermal comparative cervical test was carried out by local veterinarians from the official Brazilian Program for the Control and Eradication of Brucellosis and Tuberculosis (PNCEBT), Brazilian Ministry of Agriculture, Livestock and Supply ${ }^{13}$. The intradermal comparative cervical tuberculin test was performed according to World Organization for Animal Health-OIE based on the cervical intradermal injection of $0.1 \mathrm{~mL}$ of bovine and avian tuberculin (distance between injections about $15 \mathrm{~cm}$ ), and measuring response $72 \mathrm{~h}$ later. The cut-off value of positivity in the skin reactions of bovine site injection compared with the avian site was $>4.0 \mathrm{~mm}^{14}$.

\section{Milk sampling}

Milk samples were collected just once from the positive cows, as the official Brazilian tuberculosis control program requires euthanasia of animals diagnosed as positive in the intradermal comparative cervical tuberculin test ${ }^{13}$. One hundred and forty-two milk samples (pool from all mammary quarters of each animal) were aseptically collected in sterile tubes after teat cleaning with $1 \%$ iodine solution. Samples were immediately stored in isothermal containers $\left(4-8^{\circ} \mathrm{C}\right)$ and subsequently frozen in the laboratory $\left(-20^{\circ} \mathrm{C}\right)$ until they were used in the microbiological and molecular techniques.

\section{Mycobacterial cultures}

A $40 \mathrm{~mL}$ sample of pooled milk comprising $10 \mathrm{~mL}$ of each mammary quarter was centrifuged at 7,280 $\mathrm{g}$ for $20 \min ^{15}$ and a direct smear from the pellet was stained by Ziehl-Neelsen (ZN) for the identification of acid-fast bacilli (AFB). After that, the supernatant was discarded and the pellet was subjected to the Petroff method with some modifications ${ }^{16}$; subsequently, microbiological culture on Löwenstein-Jensen and Stonebrink media ${ }^{7}$ was carried out. Samples were kept at $37{ }^{\circ} \mathrm{C}$ in aerobic conditions up to 90 days. Colonies compatible with mycobacteria were subjected to ZN staining for the identification of AFB to perform phenotypic classification. Standard M. bovis (AN5) and M. avium (D4) strains were used as microbiological and molecular methods positive controls.

\section{DNA amplification and $h s p 65$ gene sequencing}

The genus Mycobacterium was confirmed by PCR and species classification was based on $h s p 65$ gene sequencing. DNA extraction was performed by the phenol-chloroform method. PCR amplification was carried out as described by Telenti et al. ${ }^{17}$ using the TB11 (5'-ACCAACGATGGTGTGTCCAT-3'), and TB12 (CTTGTCGAACCGC ATACCCT 5'-3') primers targeting the 441 bp fragment of the $h s p 65$ gene. The amplicon was purified with the Illustra GFX PCR DNA and Gel Band Purification (GE Healthcare Life Sciences) kits, and quantified by NanoDrop (Thermo Scientific). All samples were sequenced in forward and reverse directions by the 
Sanger method in an ABI 3500 Genetic Analyzer ${ }^{\circledR}$ (Applied Biosystems) automated sequencer.

Sequences were edited in Chromas Lite 2.6, aligned with the BioEdit 7.2.5 program using the ClustalW algorithm; consensus sequences were built for each sample and compared with GenBank sequences for species determination. A phylogenetic tree was constructed with the neighborjoining method $^{18}$ using the Mega7 software $^{19}$. Mycobacteria from previously described milk samples were used as internal roots, such as $M$. terrae, $M$. nonchromogenicum, M. gordonae, and the M. tuberculosis complex ${ }^{5}$. Corynebacterium spp. was used as one outgroup. Statistical reliability was confirmed by the Bootstrap method with 1,000 replicates. To determine the similarity of species, a dendrogram was generated based on the $h s p 65$ gene using 10 restriction enzymes.

\section{Sample size estimation}

The sample size was calculated with the open epi site based on the following parameters: the population estimated in 1,715,686 cows, in production ${ }^{20}$, a prevalence of bovine tuberculosis in the State of Paraná, Brazil, estimated to be about $3 \%{ }^{21}$, a $95 \%$ confidence level, and $5 \%$ absolute error $^{22}$. Thus, a minimum sample of 120 positive cows was estimated for the tuberculin test.

\section{RESULTS}

\section{Animals and intradermal comparative cervical tuberculin test}

From a total of 4,766 lactating cows subjected to the intradermal comparative cervical tuberculin test, 142 $(2.98 \%)[\mathrm{CI}=2.49-3.46]$ were positive. Among these 142 positive cows, age ranged from 3 to 14 years, with a mean age of $7.17 \pm 2.57$ years, and age between 3-4 years, 5-6 years, 7-8 years, 9-10 years, and $>10$ years were $19 \%$ $(\mathrm{n}=27 / 142), 28 \%(\mathrm{n}=40 / 142), 23 \%$ (32/142), 20\% (29/142) and $10 \%(14 / 142)$, respectively.

\section{Mycobacterial culture}

Out of the 142 milk samples coming from tuberculin positive cows, three $(2.1 \%)$ were $\mathrm{ZN}$-positive in the smear before culture, 12 samples $(8.4 \%)$ showed cream or orange colonies in Lowenstein-Jensen and Stonebrink media suggestive of mycobacteria observed with isolation time on average of 30 days (ranging from 17 to 46 days). Within the 12 samples, two showed two types of colonies with different morphological characteristics, comprising 14 isolates. Furthermore, all the 14 isolates were $\mathrm{ZN}$-positive after microbiological culture. The three smears $\mathrm{ZN}$-positive before microbiological culture and the 14 smears $\mathrm{ZN}$-positive after culture produced colonies compatible with mycobacteria.

\section{Molecular diagnosis}

All the 14 colonies compatible with mycobacteria yielded a $441 \mathrm{bp}$ fragment of the hsp 65 gene in PCR, confirming the Mycobacteria genus. Sequencing of the hsp65 gene identified mycobacteria species in the 14 isolates sharing more than $98 \%$ identity (Table 1) and compared with GenBank reference strains identified as follow: M. engbaekii, M. arupense, M. nonchromogenicum, and $M$. heraklionense.

The phylogenetic tree (Figure 1) shows four clusters belonging to nontuberculous mycobacteria grouped in the Mycobacterium terrae complex ${ }^{23}$. A hsp 65 gene dendrogram revealed three subclusters with $76.0 \%$ of genetic relatedness, particularly for $M$. engbaekii and $M$. arupense cluster, and for M. nonchromogenicum and $M$. heraklionense cluster (data not show).

\section{DISCUSSION}

This study revealed the occurrence of $2.98 \%$ cows positive to the intradermal comparative cervical tuberculin test for bovine tuberculosis, which can be attributed to the study target population, corresponding to lactating cows that remain in close contact with other cattle, fact that favors the infection by the pathogen ${ }^{24}$.

The detection of 14 isolates of nontuberculous mycobacteria in milk from cows positive to the tuberculin test is a finding that raises public health concern, since these opportunistic mycobacteria are emerging causes of infectious diseases in humans ${ }^{3}$ and animals ${ }^{8}$; as the species detected in this study have recently been reported as primary causes of pulmonary and extrapulmonary infections in immunocompetent and immunocompromised humans ${ }^{23,25,26}$.

M. tuberculosis complex species were not identified among mycobacteria species isolated from the milk of animals positive to the intradermal comparative cervical tuberculin test, particularly $M$. bovis. The absence of $M$. bovis identification in milk of sampled animals may be partially attributed to the intermittent shedding of pathogen to milk in bovine mammary infections ${ }^{27}$. In addition, M. bovis infections may occur in other organs without involvement of mammary glands. In this case, the animal may be positive to the intradermal comparative cervical tuberculin test without any shedding of the pathogen to 
Table 1 - Identification of the isolate, speciation, statistical measures of significance, and accession numbers of mycobacteria detected from raw milk cows according to BLAST. Brazil, 2014-2015

\begin{tabular}{lccccccc}
\hline $\begin{array}{l}\text { Isolate } \\
\text { Number }\end{array}$ & Species & $\begin{array}{c}\text { Maximum } \\
\text { Score }\end{array}$ & Total score & Cover & E-value & Identity & Access \\
\hline 1 & M. arupense & 630 & 630 & $100 \%$ & $5 \mathrm{E}-177$ & $99 \%$ & FJ263631.1 \\
2 & M. engbaekii & 634 & 634 & $100 \%$ & $4 \mathrm{E}-178$ & $99 \%$ & $\mathrm{JN} 571196.1$ \\
3 & M. arupense & 597 & 597 & $100 \%$ & $5 \mathrm{E}-167$ & $98 \%$ & $\mathrm{JF} 491325.1$ \\
4 & M. nonchromogenicum & 597 & 597 & $100 \%$ & $5 \mathrm{E}-167$ & $98 \%$ & $\mathrm{JX294382.1}$ \\
5 & M. nonchromogenicum & 636 & 636 & $100 \%$ & $1 \mathrm{E}-178$ & $99 \%$ & $\mathrm{JN} 571193.1$ \\
6 & M.engbaekii & 641 & 641 & $100 \%$ & $2 \mathrm{E}-180$ & $100 \%$ & $\mathrm{JN} 571196.1$ \\
7 & M. engbaekii & 619 & 619 & $100 \%$ & $1 \mathrm{E}-173$ & $99 \%$ & $\mathrm{JN} 571196$ \\
8 & M. heraklionense & 597 & 597 & $100 \%$ & $5 \mathrm{E}-167$ & $98 \%$ & $\mathrm{JN} 571192$ \\
9 & M. arupense & 625 & 625 & $100 \%$ & $2 \mathrm{E}-175$ & $99 \%$ & $\mathrm{JN} 571186.1$ \\
10 & M. engbaekii & 614 & 614 & $100 \%$ & $5 \mathrm{E}-172$ & $99 \%$ & $\mathrm{JN} 571196.1$ \\
11 & M. engbaekii & 641 & 641 & $100 \%$ & $2 \mathrm{E}-180$ & $100 \%$ & $\mathrm{JN} 571196.1$ \\
12 & M. nonchromogenicum & 636 & 636 & $100 \%$ & $1 \mathrm{E}-178$ & $99 \%$ & $\mathrm{JN} 571193.1$ \\
13 & M. arupense & 619 & 619 & $100 \%$ & $1 \mathrm{E}-173$ & $99 \%$ & $\mathrm{JN} 571186.1$ \\
14 & M. heraklionense & 597 & 597 & $100 \%$ & $5 \mathrm{E}-167$ & $98 \%$ & $\mathrm{JN571192}$ \\
\hline
\end{tabular}

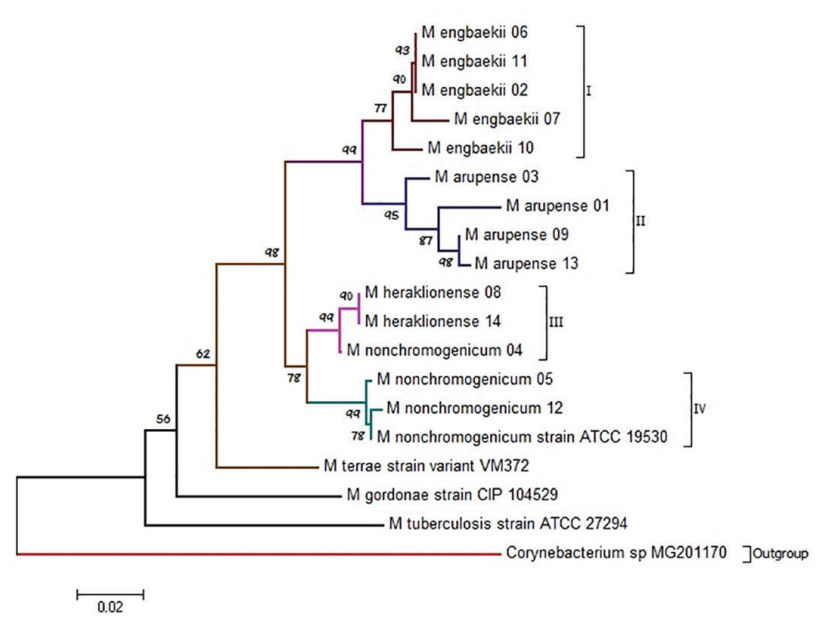

Figure 1 - Phylogenetic relationship among species of mycobacteria (M. engbaekii, $M$. arupense, $M$. nonchromogenicum, and $M$. heraklionense) identified in raw cow milk, revealing the presence of 4 clusters (I, II, III, IV). The phylogenetic tree was analyzed by the neighborjoining method and the Bootstrap test with 1,000 replicates. Botucatu, SP, Brazil, 2016

milk. This fact may be considered a main limitation of the current study, because it was not possible to obtain other milk samples or samples from organs of the animals as animals positive to the comparative intradermal test are required to be euthanized by the Brazilian Program for the Control and Eradication of Tuberculosis ${ }^{13}$. In a similar study in Argentina, in which only one milk sample was collected, none $M$. bovis isolate was detected in milk using PCR among cows positive to the comparative intradermal test ${ }^{28}$.
In this context, other authors in Belgium ${ }^{29}$ and England ${ }^{27}$ have reported only $4 \%$ and $5 \%$ of $M$. bovis, respectively, using microbiological culture in a single milk sample of cows positive to the tuberculin test. This circumstantial evidence suggests low and/or intermittent shedding of $M$. bovis in infected cows' milk, and that repeated sampling of milk from the same positive animal may increase success rates in the mammary identification of the pathogen.

Mycobacteria other than M. bovis, such as NTM, may cause cross-reactivity and the interference in the routine intradermal antemortem tests for bovine tuberculosis leading to false positive results ${ }^{30}$. In addition, geographical variations may also play a role in intradermal diagnostic failure because of differences among exposure of animals to mycobacterial species. In this scenario, a comprehensive study investigated mycobacteria obtained from bovine and deer in the United States and detected a diversity of NTM species in animals from both, abattoir and field conditions, including $M$. terrae complex; and hypothesize that NTM sampled from field conditions are more likely to interfere with current intradermal diagnostic tests for bovine tuberculosis detection ${ }^{9}$. Despite the lack of $M$. tuberculosis complex identification, particularly M. bovis in milk collected in field conditions from positive cattle to intradermal comparative cervical tuberculin test, as well as the impossibility to access organs of animals due to the need of euthanasia required by Brazilian Program against disease ${ }^{13}$, detection of NTM species from animals positive to the tuberculin test in the current study alerts to the 
possibility of interference of $M$. terrae complex species with routine intradermal antemortem tests for diagnosis of bovine tuberculosis. These factors bring economical and ethical implications, since positive animals must be slaughtered ${ }^{30}$ and there is a probability of false-positive reactions ${ }^{9}$.

Molecular detection of NTM species in cow milk in Brazil is a public health concern. Brazil has the second major commercial bovine herd in the world, estimated at 212.34 million animals. From these, about 25 million are milking cows ${ }^{31}$. Nevertheless, approximately $20 \%$ of the Brazilian milk is consumed without being officially inspected. In addition, the habit of consumption of raw milk and raw milk products remains in this country ${ }^{32}$, which increases the risk of bovine-to-human infections caused by pathogens shed in milk, including mycobacteria species.

NTM are widely distributed in the environment of dairy farms and are found in soil, manure, organic matter, plants, and water ${ }^{33}$. NTM infection of cattle predominantly occurs due to the consumption of contaminated water and food $^{34}$. Occasionally, it occurs by the intramammary route ${ }^{4}$. The detection of NTM species in dairy cows was reported in Turkey $^{5,35}$, Pakistan $^{36}$, and Tanzania ${ }^{37}$. Particularly in Brazil, NTM were described in pasteurized milk ${ }^{38,39}$. However, few studies have focused on the risk of mycobacteria elimination in cows positive to the tuberculin tests. In this scenario, Pandey et al. ${ }^{8}$ found M. bovis in $18.7 \%$ (3/16) milk samples of cows from Zambia positive to the intradermal comparative cervical tuberculin test, whereas Ben Kahla et al..$^{40}$ in Tunisia detected $4.9 \%$ (5/306) M. bovis strains in milk samples of cows positive to the single intradermal test. In Brazil, M. bovis (5.26\%), M. avium (5.26\%), M. fortuitum (10.52\%), and Mycobacterium spp. (78.95\%) were described in 780 raw milk samples from 52 cows suspected or positive to the Stormont test, although the diagnosis was based exclusively on microbiological and phenotypic methods ${ }^{41}$.

Globally, differentiation of Mycobacterium species based on molecular methods has been increasingly used in the routine diagnosis of the pathogen ${ }^{42}$. Amplification of the $h s p 65$ gene fragments ${ }^{17,43}$ or partial sequencing of this marker ${ }^{44-47}$ are reliable and valuable methods for mycobacterial identification. However, few studies have focused on sequencing of mycobacteria isolated from bovine milk, particularly from animals positive to different tuberculin tests. Indeed, among 14 mycobacterial strains recovered using microbiological culture in the current study, partial sequencing of the $h s p 65$ gene revealed $>98 \%$ similarity with species deposited in GenBank, identifying $M$. engbaekii $(\mathrm{n}=5), M$. arupense $(\mathrm{n}=4), M$. nonchromogenicum $(\mathrm{n}=3)$, and M. heraklionense $(\mathrm{n}=2)$. Besides speciation, sequencing data allowed mycobacterial detection using different clinical specimens, as well as the identification of new species, contributing to the taxonomic characterization of bacteria and to the knowledge on the diversity of potentially animal-to-human pathogenic species $^{23,46}$.

The phylogenetic tree built with the 14 isolates showed four clusters, whereas the $h s p 65$ gene dendrogram revealed three subclusters with $76.0 \%$ of genetic relatedness that were grouped in the Mycobacterium terrae complex, which has been reported causing chronic diseases with antimicrobial resistance in humans and animals ${ }^{23} . M$. heraklionense has been recently included in the Mycobacterium terrae complex $^{46}$, and was reported in cases of tenosynovitis in immunocompetent patients ${ }^{48}$, besides its isolation in 12 human immunosuppressed HIV-negative patients at the Heraklion hospital in Greece ${ }^{25}$.

M. terrae complex was characterized in 1981 including M. nonchromogenicum, M. terrae, and M. triviale species. Nevertheless, increasingly use of molecular methods in the mycobacterial diagnosis and emergence of clinical cases of human infections by NTM has enabled inclusion of new species into the $M$. terrae complex group ${ }^{46}$. Human cases of $M$. terrae complex infections are related to synovitis, osteomyelitis, and pulmonary infections ${ }^{49} . M$. arupense was described as a new mycobacterial species in $2006^{50}$ and was reported in a case of tenosynovitis in a man over 50 years of age with a primary immunosuppressing disease caused by a coinfection ${ }^{26,51}$ and in another case of tenosynovitis associated with diabetes mellitus ${ }^{52}$.

M. nonchromogenicum was reported as a causal agent of cavitary pulmonary and extrapulmonary infections in a immunocompetent patient ${ }^{53,54}$. In contrast, $M$. engbaekii was initially proposed as a species in 1972, but officially described in clinical isolates in 2013, although the pathogenicity of this mycobacterium as the primary causal agent of infections in animals or humans remains unclear. In addition, gastrointestinal clinical signs in humans caused by $M$. terrae complex infections have been reported ${ }^{55}$, related to fish ${ }^{34}$ and milk consumption ${ }^{5,37,39}$. This circumstantial evidence suggests a potential oral route of infection for $M$. terrae complex species to human, highlighting the public health concern of the current study due to the identification of this group of mycobacteria in raw milk.

Despite the existence of the official Brazilian Program for the Control and Eradication of Tuberculosis, the occurrence of about $3 \%$ lactating cows positive to mycobacteria by the intradermal comparative cervical tuberculin test should be considered high, especially because of the large dairy herd in this country and the shedding of nontuberculous mycobacteria in milk. Sequencing data identified M. engbaekii, M. arupense, 
M. nonchromogenicum, and M. heraklionense belonging to the $M$. terrae complex, which has been identified in synovitis, osteomyelitis and pneumonia, as well as in gastrointestinal human infections, suggesting a potential oral route of infection for this mycobacterial group to humans. Overall, our data adds to a global awareness of NTM as probable confounder pathogens for current intradermal testing of bovine tuberculosis. In addition, our results represent a public health concern due to the emergence of NTM as current infectious diseases in humans, which poses a risk in countries, such as Brazil, where the consumption of raw milk still exists, since some of the mycobacterial species described here have been reported as primary agents of infections in both immunocompetent and immunosuppressed humans.

\section{ACKNOWLEDGMENTS}

To the National Council for Scientific and Technological Development (CNPq), Brazil, grant No 455649/2014-6. $\mathrm{MBH}$ is indebted to CNPq for the fellowship received. CADB is grateful to Coordination for the Improvement of Higher Education Personnel (CAPES) for the fellowship received.

\section{REFERENCES}

1. Rastogi N, Legrand E, Sola C. The mycobacteria: an introduction to nomenclature and pathogenesis. Rev Sci Tech. 2001;20:2154.

2. Johnson MM, Odell JA. Nontuberculous mycobacterial pulmonary infections. J Thorac Dis. 2014;6:210-20.

3. Honda JR, Hasan NA, Davidson RM, Williams MD, Epperson LE, Reynolds PR, et al. Environmental nontuberculous mycobacteria in the Hawaiian Islands. PLoS Negl Trop Dis. 2016;10:e0005068.

4. Radostits OM, Gay CC, Hinchcliff KW, Constable PD, editors. Veterinary medicine: a textbook of the diseases of cattle, horses, sheep, pigs, and goats. $10^{\text {th }}$ ed. Philadelphia: Saunders Elsevier; 2007.

5. Konuk M, Korcan E, Dülgerbaki S, Altindis M. Isolation and identification of mycobacteria from raw milk samples in Afyonkarahisar district of Turkey. Int J Food Microbiol. 2007;115:343-7.

6. LoBue PA, Enarson DA, Thoen CO. Tuberculosis in humans and animals: an overview. Int J Tuberc Lung Dis. 2010;14:1075-8.

7. Quinn PJ, Markey BK, Leonard FC, Fitzpatrick ES, Fanning S, Hartigan PJ. Veterinary microbiology and microbial disease. $2^{\text {nd }}$ ed. Oxford: Wiley-Blackwell; 2011.

8. Pandey GS, Hang' ombe BM, Mushabati F, Kataba A. Prevalence of tuberculosis among southern Zambian cattle and isolation of Mycobacterium bovis in raw milk obtained from tuberculin positive cows. Vet World. 2013;6:986-91.

9. Thacker TC, Robbe-Austerman S, Harris B, Van Palmer M, Waters WR. Isolation of mycobacteria from clinical samples collected in the United States from 2004 to 2011. BMC Vet Res. 2013;9:100.

10. Kim H, Kim SH, Shim TS, Kim MN, Bai GH, Park YG, et al Differentiation of Mycobacterium species by analysis of the heat-shock protein 65 gene (hsp65). Int J Syst Evol Microbiol. 2005;55:1649-56.

11. Bolaños CA, Paula CL, Guerra ST, Franco MM, Ribeiro MG. Diagnosis of mycobacteria in bovine milk: an overview. Rev Inst Med Trop São Paulo. 2018;60:e40.

12. Devallois A, Goh KS, Rastogi N. Rapid identication of mycobacteria to species level by PCR-restriction fragment length polymorphism analysis of the hsp65 gene and proposition of an algorithm to differentiate 34 mycobacterial species. J Clin Microbiol. 1997;35:2969-73.

13. Brasil. Ministério da Agricultura, Pecuária e Abastecimento. Secretaria de Defesa Agropecuária. Departamento de Saúde Animal. Programa Nacional de Controle e Erradicação da Brucelose e da Tuberculose Animal (PNCEBT). Brasília: Ministério da Agricultura, Pecuária e Abastecimento; 2006.

14. World Organization for Animal Health. Manual of diagnostic tests and vaccines for terrestrial animals (mammals, birds and bees). Paris: World Organization for Animal Health; 2008.

15. Franco MM, Paes AC, Ribeiro MG, Pantoja JC, Santos AC, Miyata $\mathrm{M}$, et al. Occurrence of mycobacteria in bovine milk samples from both individual and collective bulk tanks at farms and informal markets in the southeast region of Sao Paulo, Brazil. BMC Vet Res. 2013;9:85.

16. Balian SC, Pinheiro SR, Guerra JL, Morais ZM, Ferreira F, Ferreira Neto JS. Estudo comparativo de dois métodos de descontaminação na pesquisa de micobactérias. Arq Inst Biol. 2002;69:11-4.

17. Telenti A, Marchesi F, Balz M, Bally F, Böttger EC, Bodmer T. Rapid identification of mycobacteria to the species level by polymerase chain reaction and restriction enzyme analysis. $\mathrm{J}$ Clin Microbiol. 1993;31:175-8.

18. Saitou N, Nei M. The neighbor-joining method: a new method for reconstructing phylogenetic trees. Mol Biol Evol. 1987;4:40625.

19. Kumar S, Stecher G, Tamura K. MEGA7: Molecular Evolutionary Genetics Analysis version 7.0 for bigger datasets. Mol Biol Evol. 2016;33:1870-4.

20. Paraná. Secretaria de Estado da Agricultura e do Abastecimento. Departamento de Economia Rural. Análise da conjuntura agropecuária: leite, ano 2014.. [cited 2017 Dec 5]. Available from: http://www.agricultura.pr.gov.br/arquivos/File/deral/ Prognosticos/bovinocultura_leite_14_15.pdf 
21. Paes AC, Franco MM. Tuberculose em animais de produção. In: Megid J, Ribeiro MG, Paes AC, organizadores. Doenças infecciosas em animais de produção e de companhia. Rio de Janeiro: Roca; 2016. p. 512-42

22. Thrusfield M. Veterinary epidemiology. $3^{\text {th }}$ ed. Oxford: Blackwell Science; 2007.

23. Ngeow YF, Wong YL, Tan JL, Hong KW, Ng HF, Ong BL, et al. Identification of new genomospecies in the Mycobacterium terrae complex. PLoS One. 2015;10:e0120789.

24. Perez AM, Ward MP, Charmandarián A, Ritacco V. Simulation model of within-herd transmission of bovine tuberculosis in Argentine dairy herds. Prev Vet Med. 2002;54:361-72.

25. Neonakis IK, Spandidos DA, Gitti Z. Mycobacterium heraklionense sp. nov.: a case series. Exp Ther Med. 2015;10:1401-3

26. Lopez FK, Miley M, Taiwo B. Mycobacterium arupense as an emerging cause of tenosynovitis. Emerg Infect Dis. 2016;22:559-61.

27. Goodchild AV, Clifton-Hadley RS. Cattle-to-cattle transmission of Mycobacterium bovis. Tuberculosis (Edinb.). 2001;81:23-41.

28. Pérez A, Reniero A, Forteis S, Meregalli B, López B, Ritacco V. Estudio de Mycobacterium bovis en leche mediante métodos bacteriológicos y reacción em cadena de la polimerasa. Rev Argent Microbiol. 2002;34:45-51.

29. Sinha RN. Mycobacterium tuberculosios. In: International Dairy Federation. The significance of pathogenic microorganisms in raw milk. Brussels: International Dairy Federation; 1994. p. 117-67.

30. Michel AL. Mycobacterium fortuitum infection interference with Mycobacterium bovis diagnostics: natural infection cases and a pilot experimental infection. J Vet Diagn Invest. 2008;20:501-3.

31. Instituto Brasileiro de Geografia e Estatística. Produção da pecuária municipal 2014. Rio de Janeiro: IBGE; 2014.

32. Motta RG, Silva AV, Giuffrida R, Siqueira AK, Paes AC, Motta IG, et al. Indicadores de qualidade e composição de leite informal comercializado na região sudeste do estado de São Paulo. Pesq Vet Bras. 2015;35:417-23.

33. Chang C, Wang LY, Liao CY, Huang SP. Identification of nontuberculous mycobacteria existing in tap water by pcrrestriction fragment length polymorphism. Appl Environ Microbiol. 2002;68:3159-61.

34. Mediel MJ, Rodriguez V, Codina G, Martin-Casabona N. Isolation of mycobacteria from frozen fish destined for human consumption. Appl Environ Microbiol. 2000;66:3637-8.

35. Aydin F, Ulger M, Emekda G, Aslan G, Günal S. Isolation and identification of mycobacterium bovis and non-tuberculous mycobacteria in raw milk samples in Mersin province. Mikrobiyol Bul. 2012;46:283-9.

36. Qamar MF, Azhar T. Detection of Mycobacterium from bovine milk in Lahore, Pakistan. Sci Int (Lahore). 2013;25:353-7.
37. Kazwala RR, Daborn CJ, Kusiluka LJ, Jiwa SF, Sharp JM, Kambarage DM. Isolation of Mycobacterium species from raw milk of pastoral cattle of the southern highlands of Tanzania. Trop Anim Health Prod. 1998;30:233-9.

38. Leite CQ, Anno IS, Leite SR, Roxo E, Morlock GP, Cooksey RC. Isolation and identification of mycobacteria from livestock specimens and milk obtained in Brazil. Mem Inst Oswaldo Cruz. 2003;98:319-23.

39. Sgarioni SA, Hirata RD, Hirata MH, Leite CQ, Prince KA, Leite SR, et al. Occurrence of Mycobacterium bovis and nontuberculous mycobacteria (NTM) in raw and pasteurized milk in the northwestern region of Paraná, Brazil. Braz J Microbiol. 2014;45:707-11.

40. Ben IK, Boschiroli ML, Soussi F, Cherif N, Benzarti M, Boukadida $\mathbf{J}$, et al. Isolation and molecular characterization of Mycobacterium bovis from raw milk in Tunisia. Afr Health Sci. 2011;11 Suppl 1:S2-S5.

41. Pardo RB, Langoni H, Mendonça LJ, Chi KD. Isolation of Mycobacterium spp. in milk from cows suspected or positive to tuberculosis. Braz J Vet Res Anim Sci. 2001;38:284-7.

42. Pourahmad F, Thompson KD, Adams A, Richards RH. Comparative Evaluation of Polymerase chain reactionrestriction enzyme analysis (PRA) and sequencing of heat shock protein 65 (hsp65) gene for identification of aquatic mycobacteria. J Microbiol Methods. 2009;76:128-35.

43. Plikaytis BB, Plikaytis BD, Yakrus MA, Butler WR, Woodley CL, Silcox VA, et al. Differentiation of slowly growing Mycobacterium species, including Mycobacterium tuberculosis, by gene amplification and restriction fragment length polymorphism analysis. J Clin Microbiol. 1992;30:1815-22.

44. Ringuet H, Akoua-Koffi C, Honore S, Varnerot A, Vincent V, Berche $\mathrm{P}$, et al. hsp65 sequencing for identification of rapidly growing. J Clin Microbiol. 1999;37:852-7.

45. McNabb A, Eisler D, Adie K, Amos M, Rodrigues M, Stephens $\mathrm{G}$, et al. Assessment of partial sequencing of the 65-kilodalton heat shock protein gene (hsp65) for routine identification of Mycobacterium species isolated from clinical sources. J Clin Microbiol. 2004;42:3000-11.

46. Tortoli E, Gitti Z, Klenk HP, Lauria S, Mannino R, Mantegani P, et al. Survey of 150 strains belonging to the Mycobacterium terrae complex and description of Mycobacterium engbaekii sp. nov., Mycobacterium heraklionense sp. nov. and Mycobacterium longobardum sp. nov. Int J Syst Evol Microbiol. 2013;63:401-11.

47. Escobar-Escamilla N, Ramírez-González JE, González-Villa M, Torres-Mazadiego P, A Mandujano-Martínez, Barrón-Rivera C, et al. hsp65 phylogenetic assay for molecular diagnosis of nontuberculous mycobacteria isolated in Mexico. Arch Med Res. 2014;45:90-7.

48. Abedalthagafi M, Rosenberg O, Miller S. First report of tenosynovitis in an immunocompetent person caused by $\mathrm{M}$. heraklionense. J M M Case Rep. 2014;1:1-3. 
49. Vasireddy R, Vasireddy S, Brown-Elliot BA, Wenganack NL, Eke UA, Benwill JL, et al. Mycobacterium arupense, Mycobacterium heraklionense, and a newly proposed species, "Mycobacterium virginiense" sp. nov., but not Mycobacterium nonchromogenicum, as species of the Mycobacterium terrae complex causing tenosynovitis and osteomyelitis. J Clin Microbiol. 2016;54:1340-51.

50. Cloud JL, Meyer JJ, Pouder JJ, Jost KC Jr, Sweeney A, Carroll KC, et al. Mycobacterium arupense sp. nov., a non-chromogenic bacterium isolated from clinical specimens. Int J Syst Evol Microbiol. 2006;56:1413-8.

51. Beam E, Vasoo S, Simner PJ, Rizzo M, Mason EL, Walker RC, et al. Mycobacterium arupense flexor tenosynovitis: case report and review of antimicrobial susceptibility profiles for 40 clinical isolates. J Clin. Microbiol. 2014;52:2706-8.
52. Tsai TF, Lai CC, Tsai IC, Chang CH, Hsiao CH, Hsueh PH. Tenosynovitis caused by Mycobacterium arupense in a patient with diabetes mellitus. Clin Infect Dis. 2008;47:861-3.

53. Halstrom S, Price P, Thomson R. Review: environmental mycobacteria as a cause of human infection. Int J Mycobacteriol. 2015;4:81-91.

54. Gentry CA. Atypical mycobacteria. [cited 2017 Dec 5]. Available from: https://www.accp.com/docs/bookstore/psap/ p5b6sample02.pdf.

55. Fujisawa K, Watanabe H, Yamamoto K, Nasu T, Kitahara Y, Nakano M. Prymary atypical micobacteriosis of the instestine: a report of three cases. Gut. 1989;30:541-5. 